\title{
Pengaruh Pelatihan, Motivasi Dan Budaya Organisasi Terhadap Kinerja Karyawan Pada PT Bank Mandiri, Tbk Di Jakarta
}

\author{
${ }^{1}$ Widhi Wicaksono, ${ }^{2}$ Suyatin, ${ }^{3}$ Denok Sunarsi, ${ }^{4}$ Azhar Affandi, ${ }^{5}$ Herling \\ ${ }^{1.2 .3}$ Universitas Pamulang, Tangerang Selatan, Banten, Indonesia \\ ${ }^{4}$ Universitas Pasundan, Bandung, Jawa Barat, Indonesia \\ ${ }^{5}$ Universitas Negeri Makassar, Sulawesi Selatan, Indonesia \\ Email:․ㅣosen01049@unpam.ac.id
}

(Diterima: Juli 2021; Direvisi: Agustus 2021; Dipublikasikan: September 2021)

\begin{abstract}
ABSTRAK
Penelitian ini bertujuan untuk mengetahui pengaruh pelatihan, motivasi dan budaya organisasi terhadap kinerja karyawan pada PT. Bank Mandiri, Tbk di Jakarta. Metode yang digunakan adalah explanatory research dengan teknik analisis menggunakan analisis statistik dengan pengujian regresi, korelasi, determinasi dan uji hipotesis. Hasil penelitian ini pelatihan berpengaruh signifikan terhadap kinerja karyawan sebesar 37,0\%, uji hipotesis diperoleh $\mathrm{t}$ hitung $>\mathrm{t}$ tabel atau $(7,533>1,984)$. Motivasi berpengaruh signifikan terhadap kinerja karyawan sebesar 42,1\%, uji hipotesis diperoleh $t$ hitung > $t$ tabel atau $(8,499>1,984)$. Budaya organisasi berpengaruh signifikan terhadap kinerja karyawan sebesar $37,1 \%$, uji hipotesis diperoleh $t$ hitung $>t$ tabel atau $(7,597>1,984)$. Pelatihan, motivasi dan budaya organisasi secara simultan berpengaruh signifikan terhadap kinerja karyawan dengan persamaan regresi $\mathrm{Y}=6,746+0,243 \mathrm{X} 1+0,304 \mathrm{X} 2+$ 0,370X3. Kontribusi pengaruh sebesar 55,5\%, uji hipotesis diperoleh $\mathrm{F}$ hitung $>\mathrm{F}$ tabel atau $(39,934>2,470)$.
\end{abstract}

\section{Kata Kunci: Pelatihan, Motivasi, Budaya Organisasi, Kinerja Karyawan}




\section{PENDAHULUAN}

\section{Latar Belakang Masalah}

Pada era globalisasi ini perusahaaan harus mampu memaksimalkan kinerja karyawan yang lebih baik guna mencapai hasil yang maksimal. Bagi organisasi adanya pelatihan diharapkan mampu memberikan nilai tambah berupa kemampuan karyawan dalam melaksanakan tugasnya dan memiliki disiplin kerja yang tinggi sehingga akan menjamin terpeliharanya tata tertib dan kelancaran pelaksanaan tugas, sehingga diperoleh hasil optimal, adapun bagi karyawan akan diperoleh hasil yang optimal, adapun bagi karyawan akan diperoleh suasana kerja yang menyenangkan sehingga akan menambah semangat kerja dalam melaksanakan pekerjaannya, dengan demikian, karyawan dapat melaksanakan tugasnya dengan penuh kesadaran serta dapat mengembangkan tenaga dan pikiran nya semaksimal mungkin demi terwujudnya tujuan organisasi.

Menurut UU Perbankan No. 10 Tahun 1998, bank adalah badan usaha yang menghimpun dana dari masyarakat dalam bentuk simpanan dan menyalurkannya kepada masyarakat dalam bentuk kredit atau bentuk-bentuk lainnya dalam rangka meningkatkan taraf hidup orang banyak. Oleh karena itu, peranan perbankan sangat mempengaruhi kegiatan ekonomi suatu Negara. Semakin maju suatu Negara maka semakin besar peranan perbankan dalam mengendalikan ekonomi Negara tersebut. Bank yang ingin berkembang harus dapat memberikan kualitas pelayanan yang baik dan memberikan rasa aman kepada nasabah, karena hal itu merupakan salah satu faktor penentu keberhasilan dari suatu bank. Dengan memberikan kualitas pelayanan yang baik dan rasa aman kepada nasabah, maka akan menimbulkan suatu kepuasan bagi nasabah dan sebaliknya.

Sesuai dengan paparan diatas tersebut, PT. Bank Mandiri Tbk, yang merupakan perusahaan yang bergerak di bidang perbankan, yang kegiatanya mwnghimpun dana dari masyarakat (berupa tabungan, giro, deposito, dan investasi) dan menyalurkannya kepada masyarakat berupa pemberian kredit. Oleh karnanya, Bank Mandiri menyadari akan pentingnya menjaga dan mensehatkan kinerjanya dalam upaya mempertahankan ekistensi bisnis melalui peningkatan profitabilitas.

Pelatihan menjadi hal yang cukup penting dalam manajemen sumber daya manusia baik untuk professional dan manager. Pelatihan untuk karyawan sangat penting, sejak diketahui bahwa pengetahuan orang diperoleh dari pendidikan formal tidak lah cukup atau kurang sesuai bagi perusahaan. Menurut Sinambela (2016:168) dalam pandangan manajemen modern sekarang ini, manusia tidak lagi hanya diposisikan sekedar sebagai sumber daya utama, tetapi lebih dari itu, yakni bahwa manusia itu sudah menjadi asset organisasi di masa depan atau yang lebih 
populer dikenal dengan konsep human capital. Pelatihan yang dirancang dengan baik sesungguhnya dapat diukur manfaatnya seperti peningkatan kesehatan dan kinerja manajer maupun karyawan.

Menurut Mangkunegara (2013) mengemukakan bahwa "Pelatihan (training) adalah suatu proses pendidikan jangka pendek yang mempergunakan prosedur sistematis dan terorganisasi, karyawan non manajerial mempelajari pengetahuan dan keterampilan teknis dalam tujuan yang terbatas". Semakin banyak karyawan yang diberikan kesempatan untuk mengikuti pelatihan dapat meningkatkan kinerja perusahaan. Namun pada kenyataannya hal ini justru kurang mendapatkan prioritas oleh pihak manajemen perusahaan terbukti dari data yang terkumpul menunjukkan kondisi yang fluktuasi.

Salah satu faktor penting yang dapat mempengaruhi kinerja yaitu motivasi. Kurangnya motivasi terhadap pegawai dapat mengakibakan menurunya kinerja pegawai. Hal ini terlihat dari beberapa dimensi yang tidak menunjukkan perkembangan yang baik, semangat dalam menyelesaikan tugas dan kewajibannya kurang bahkan cenderung menunda-nunda. Hal lain juga menunjukkan bahwa ternyata motivasi pegawai rendah pada PT. Bank Mandiri Jakarta Hal ini dapat menjadi salah satu faktor yang menyebabkan kinerja pegawai menurun.
Setiap organisasi mempunyai karakteristik atau jati diri yang khas, artinya bahwa setiap organisasi mempunyai kepribadian tersendiri. Salah satu faktor yang membedakan suatu organisasi dari organisasi yanglainnya adalah budayanya. Budaya organisasi berkaitan dengan bagaimana pegawai menerima nilai-nilai budaya organisasi. Menurut Victor Tan dalam Wibowo (2012:349) Budaya Organisasi adalah cara melakukan sessutau dalam organisasi. Budaya organisasi merupakan satuan norma yang terdiri dari keyakinan, sikap, core values, dan pola perilaku yang dilakukan orang dalam organisasi Menurut Siagian (2012) Budaya Organisasi ialah kemauan, kemampuan dan kesediaan seseorang menyesuaikan perilakunya dengan budaya organisasi, mempunyai relevansi tinggi dengan kemauan, kemampuan dan kesediaannya meningkatkan produktivitas kerjanya.

Suatu organisasi atau perusahaan akan membutuhkan karyawan yang memiliki kinerja yang baik. Kinerja yang baik tentunya akan didukung oleh semua fasilitas yang disediakan oleh organisasi atau perusahaan tersebut.

Menurut Anwar Prabu Mangkunegara (2010: 67) Kinerja adalah hasil kerja secara kualitas dan kuantitas yang dicapai oleh seorang pegawai dalam melaksanakan tugasnya sesuai dengan tanggung jawab yang diberikan kepadanya. 
Faktor-faktor yang dapat mempengaruhi kinerja seseorang sangatlah kompleks. Sutermeister dalam Riduwan (2013) menggambarkan faktor-faktor tersebut diantaranya: latihan dan pengalaman kerja, pendidikan, sikap kepribadian, organisasi, para pemimpin, kondisi sosial, kebutuhan individu, kondisi fisik tempat kerja, kemampuan, motivasi kerja dan sebagainya. Kemudian ada pula faktor-faktor yang secara tidak langsung mempengaruhi kinerja menurut Cahyono dalam Riduwan (2013) antara lain: manusia, modal, metode, faktor produksi, faktor lingkungan organisasi, faktor lingkungan Negara, faktor lingkungan regional dan umpan balik. PT. Bank Mandiri, Tbk adalah suatu perusahaan swasta yang sudah berdiri cukup lama masih memiliki sumber daya manusia yang perlu di lakukan pembenahan. Masih banyak karyawan yang secara jobdesk banyak melakukan satu pekerjaan, namun terpaksa melakukan pekerjaan yang lain. Hal inilah yang membuat semua karyawan merasa tidak nyaman. Karena karyawan yang mengerjakan pekerjaan lebih dari satu pekerja. Dan tidak ada bedanya dengan karyawan yang hanya mengerjakan satu pekerjaan saja. Tidak ada kompensasi atau tunjangan atau insentif lebih yang didapatkan dari manajemen untuk hasil mengerjakan pekerjaan lebih dari satu. Hal itu hanya dilakukan secara sukarela oleh para karyawannya. Sehingga kurangnya rasa tanggung jawab dan semangat kerja, tentunya kebutuhan akan SDM menjadi masalah yang harus diperhatikan oleh manajemen dari PT. Bank Mandiri, Tbk.

Berdasarkan uraian latar belakang di atas, maka peneliti tertarik untuk membuat penelitian dengan judul "Pengaruh Pelatihan, Motivasi dan Budaya Organisasi Terhadap Kinerja Karyawan Pada PT. Bank Mandiri Tbk di Jakarta".

\section{Rumusan Masalah}

a. Adakah pengaruh pelatihan terhadap kinerja karyawan pada PT. Bank Mandiri, Tbk di Jakarta?

b. Adakah pengaruh motivasi terhadap kinerja karyawan pada PT. Bank Mandiri, Tbk di Jakarta ?

c. Adakah pengaruh budaya organisasi terhadap kinerja karyawan pada PT. Bank Mandiri, Tbk di Jakarta?

d. Adakah pengaruh secara simultan pelatihan, motivasi dan budaya organisasi terhadap kinerja karyawan pada PT. Bank Mandiri, Tbk di Jakarta?

\section{Tujuan Penelitian}

a. Untuk mengetahui pengaruh pelatihan terhadap kinerja karyawan pada PT. Bank Mandiri, Tbk di Jakarta.

b. Untuk mengetahui pengaruh motivasi terhadap kinerja karyawan pada PT. Bank Mandiri, Tbk di Jakarta.

c. Untuk mengetahui pengaruh budaya organisasi terhadap kinerja karyawan pada PT. Bank Mandiri, Tbk di Jakarta.

d. Untuk mengetahui pengaruh secara simultan pelatihan, motivasi dan budaya organisasi 
terhadap kinerja karyawan pada PT. Bank Mandiri, Tbk di Jakarta.

\section{TINJAUAN PUSTAKA}

\section{Pelatihan}

Pelatihan menurut Rivai (2019:240) adalah proses secara sistematis mengubah tingkah laku pegawai untuk mencapai tujuan organisasi. Pelatihan berkatian dengan keahlian dan kemampuan pegawai untuk melaksanakan pekerjaan saat ini. Pelatihan memiliki orientasi saat ini dan membantu pegawai untuk mencapai kehalian dan kemampuan tertentu agar berhasil dalam melaksanakan pekerjaanya

\section{Motivasi}

Menurut Maslow dalam Sutrisno (2019:55), menyatakan bahwa motivasi adalah pemberian daya penggerak yang menciptakan kegairahan kerja seseorang, agar mereka mau bekerja sama, bekerja efektif dan terintegrasi dengan segala upayanya untuk mencapai kepuasan dalam bekerja.

\section{Budaya Organisasi}

Yang dimaksud budaya organisasi dalam penelitian ini mengacu pada pendapat Rivai (2015:240) yang dimaksud budaya organisasi dalam penelitian ini "Proses secara sistematis mengubah tingkah laku pegawai untuk mencapai tujuan organisasi. Budaya organisasi berkatian dengan keahlian dan kemampuan pegawai untuk melaksanakan pekerjaan". Adapun indikator yang digunakan dalam penelitian ini meliputi: Materi budaya organisasi, metode budaya organisasi, kemampuan instruktur, peserta budaya organisasi dan evaluasi budaya organisasi

\section{Kinerja Karyawan}

Yang dimaksud kinerja dalam penelitian mengacu pada pendapat Mangkunegara (2016:75) yaitu hasil kerja secara kualitas dan kuantitas yang dicapai oleh seorang pegawai dalam melaksanakan tugasnya sesuai dengan tanggung jawab yang diberikan kepadanya. Adapun indikator yang digunakan meliputi: 1) Kualitas, 2) kuantitas, 3) pelaksanaan tugas, 4) tanggung jawab pekerjaan.

\section{Model Penelitian}

Menurut pendapat Sugiyono (2018) "Model penelitian merupakan sintesa yang mencerminkan keterkaitan antara variabel yang diteliti dan merupakan tuntunan untuk memecahkan masalah penelitian serta merumuskan hipotesis yang berbentuk bagan alur yang dilengkapi penjelasan kualitatif". Dalam penelitian ini model penelitian yang dibuat sebagai berikut:

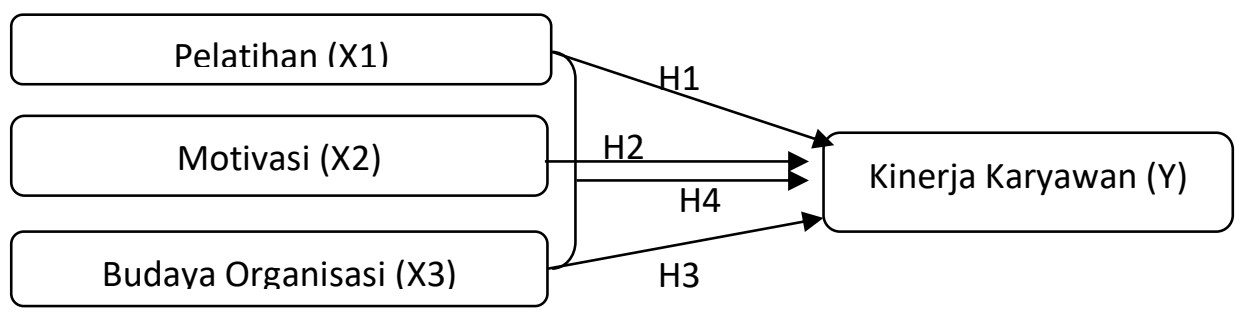

Gambar 1. Paradigma Model Penelitian 


\section{Hipotesis Penelitian}

Hipotesis yang peneliti ajukan adalah sebagai berikut:

H1 : Diduga terdapat pengaruh yang signifikan pelatihan terhadap kinerja karyawan pada PT. Bank Mandiri, Tbk di Jakarta.

$\mathrm{H} 2$ : Diduga terdapat pengaruh yang signifikan motivasi terhadap kinerja karyawan pada PT. Bank Mandiri, Tbk di Jakarta.

H3 : Diduga terdapat pengaruh yang signifikan budaya organisasi terhadap kinerja karyawan pada PT. Bank Mandiri, Tbk di Jakarta.

H4 : Diduga terdapat pengaruh yang signifikan pelatihan, motivasi dan budaya organisasi secara simultan terhadap kinerja karyawan pada PT. Bank Mandiri, Tbk di Jakarta.

\section{METODE PENELITIAN}

\section{Populasi}

Populasi merupakan sekumpulan objek yang ditentukan melalui suatu kriteria tertentu yang akan dikategorikan ke dalam objek yang akan diteliti. Menurut Sugiyono (2018) mendefinisikan populasi adalah jumlah wilayah generalisasi yang terdiri atas obyek atau subyek yang mempunyai kualitas dan karakteristik yang ditetapkan oleh peneliti dan kemudian ditarik kesimpulannya. Adapun populasi dalam penelitian berjumlah 132 responden PT. Bank Mandiri, Tbk di Jakarta

\section{Sampel}

Menurut Sugiyono (2018) yaitu "Sampel adalah jumlah dan karakteristik yang dimiliki oleh populasi tersebut". Sedangkan Suharsini Arikunto (2010) berpendapat bahwa "Sampel adalah sebagian atau wakil populasi yang diteliti". Teknik pengambilan sampling dalam penelitian ini menggunakan rumus Slovin dengan tingkat error 0,05 dan diperoleh sampel sebanyak 100 responden.

\section{Jenis Penelitian}

Jenis penelitian yang dipakai adalah kuantitatif, dimana tujuannya adalah untuk mengetahui mencari keterhubungan antara

\section{Metode Analisis Data}

Dalam menganalisis data digunakan uji instrumen, uji asumsi klasik, regresi, koefisien korelasi, koefisien determinasi dan uji hipotesis.

\section{HASIL PENELITIAN}

\section{Uji Intrumen}

Pada pengujian ini digunakan uji validitas dan uji reliabilitas. Uji validitas dimaksudkan untuk mengetahui ketepatan data tentang kesesuaian antara yang mau diukur dengan hasil pengukurannya. Menurut Sugiyono (2018) "Valid berarti terdapat kesamaan antara data yang terkumpul dengan data yang sesungguhnya". Sedangkan Ghozali (2013) berpendapat "Suatu kuesioner dikatakan valid jika pertanyaan pada kuesioner mampu untuk mengungkapkan sesuatu yang akan diukur oleh kuesioner tersebut". Untuk melakukan uji validitas dilihat nilai signifikansi 2 tailed dibandingkan dengan 0,05 dengan 
dengan ketentuan:

1) Jika nilai signifikansi 2 talied $<0,05$, maka instrumen valid,

2) Jika nilai signifikansi 2 talied $>0,05$, maka instrumen tidak valid,

Dari hasil pengujian diperoleh masing-masing item pernyataan pseluruh variabel diperoleh nilai signifikansi 2 tailed sebesar $0,000<0,05$, dengan demikian instrumen valid.

Uji berikutnya adalah uni reliabilitas. Model analisis uji reliabiltas yang digunakan dalam penelitian ini adalah model Alpha Cronbach. Menurut Ghozali (2013) berpendapat "reliabilitas merupakan alat untuk menguji kekonsistenan jawaban responden atas pertanyaan di kuesioner. Suatu kuesioner dikatakan reliabel jika jawaban seseorang terhadap pertanyaan adalah konsisten atau stabil dari waktu ke waktu”. Dalam pengukurannya dilakukan dengan analisis Cronbach's Alpha. Ghozali (2013) mengklasifikasikan nilai Cronbach's Alpha sebagai berikut:

1) Jika nilai Cronbach's Alpha > 0,600, maka dinyatakan reliabel,

2) Jika nilai Cronbach's Alpha < 0,600, maka dinyatakan tidak reliabel,

Adapun hasil pengujiannya sebagai berikut:

Tabel 1. Hasil Pengujian Reliabilitas

\begin{tabular}{|c|c|c|c|}
\hline Variabel & $\begin{array}{c}\text { Cronbach's } \\
\text { Alpha }\end{array}$ & $\begin{array}{c}\text { Standar Kritis } \\
\text { Alpha }\end{array}$ & Keterangan \\
\hline Pelatihan (X1) & 0.673 & 0.600 & Reliabel \\
\hline Motivasi (X2) & 0.703 & 0.600 & Reliabel \\
\hline Budaya Organisasi (X3) & 0.666 & 0.600 & Reliabel \\
\hline Kinerja Karyawan (Y) & 0.642 & 0.600 & Reliabel \\
\hline
\end{tabular}

Berdasarkan hasil pengujuan di atas, Keseluruhan variabel pelatihan (X1), motivasi (X2), budaya organisasi (X3) dan kinerja karyawan (Y) diperoleh nilai cronbach alpha lebih besar dari 0,600. Dengan demikian dinyatakan reliabel.

\section{Uji Asumsi Klasik}

Uji asumsi klasik dimaksudkan untuk mengetahui ketepatan sebuah data. Menurut Singgih Santoso (2011) "Sebuah model regresi akan digunakan untuk melakukan peramalan, sebuah model yang baik adalah model dengan kesalahan peramalan yang seminimal mungkin". Karena itu, sebuah model sebelum digunakan seharusnya memenuhi beberapa asumsi, yang biasa disebut asumsi klasik. Dalam penelitian ini uji asumsi klasik yang digunakan adalah meliputi: Uji Normalitas, Uji Multikolinearitas, Uji Autokorelasi, dan Uji Heterokedastisitas. Adapun hasilnya sebagai berikut:

\section{a. Uji Normalitas}

Uji normalitas dilakukan untuk menguji apakah dalam model regresi, variabel dependen dan variabel independen berdistribusi normal atau berdistribusi tidak normal. Hasil uji normalitas dengan alat uji KolmogorovSmirnov Test, sebagai berikut: 
Tabel 2. Hasil Normalitas Kolmogorov-Smirnov

\begin{tabular}{|c|c|c|c|c|c|c|}
\hline & Tests & Norm & & & & \\
\hline & Kolm & ov-Smir & & Shap & -Wilk & \\
\hline & Statistic & df & Sig. & Statistic & df & Sig. \\
\hline Kinerja Karyawan (Y) & .071 & 100 & $.200^{*}$ & .989 & 100 & .611 \\
\hline
\end{tabular}

Berdasarkan hasil pengujian pada tabel diatas diperoleh nilai signifikansi 0,200 dimana nilai tersebut lebih besar dari nilai $\alpha=$ 0,050 atau $(0,061>0,050)$. Dengan demikian maka asumsi distribusi persamaan pada uji ini adalah normal.

\section{b. Uji Multikonilieritas}

Pengujian

mutlikolinearitas dilakukan

untuk meyakini bahwa antar

Tabel 3. Hasil Uji Multikolinieritas dengan Collinierity Statistic

\section{Coefficients}

\begin{tabular}{|c|c|c|c|c|c|c|}
\hline \multirow{2}{*}{\multicolumn{2}{|c|}{ Model }} & \multicolumn{2}{|c|}{$\begin{array}{l}\text { UnstSayardized } \\
\text { Coefficients }\end{array}$} & \multirow{2}{*}{$\begin{array}{c}\text { StSayardized } \\
\text { Coefficients } \\
\text { Beta }\end{array}$} & \multirow{2}{*}{$\begin{array}{l}\text { Collinearit } \\
\text { Tolerance }\end{array}$} & \multirow{2}{*}{$\begin{array}{l}\text { tatistics } \\
\text { VIF }\end{array}$} \\
\hline & & $\mathrm{B}$ & Std. Error & & & \\
\hline & (Constant) & 6.746 & 2.934 & & & \\
\hline & Pelatihan (X1) & .243 & .081 & .262 & .602 & 1.661 \\
\hline & Motivasi (X2) & .304 & .085 & .326 & .553 & 1.807 \\
\hline & Budaya organisasi (X3) & .292 & .080 & .304 & .664 & 1.505 \\
\hline
\end{tabular}

a. Dependent Variable: Kinerja Karyawan (Y)

Berdasarkan hasil pengujian pada tabel diatas nilai tolerance pelatihan sebesar 0,602 , motivasi sebesar 0,553 , budaya organisasi sebesar $0,664<1,0$ dan nilai Variance Inflation Factor (VIF) variabel pelatihan sebesar 1,661, motivasi sebesar 1,807 , budaya organisasi sebesar 1,505. Ddengan demikian model variabel bebas tidak memiliki multikolinearitas atau tidak memiliki pengaruh korelasi antara variabel yang ditetapkan sebagai model dalam penelitian. Uji multikolinearitas dilakukan dengan melihat nilai Tolerance Value dan Variance Inflation Factor (VIF). Adapun hasil pengujiannya sebagai berikut: 
Hasil pengujian pada tabel diatas diperoleh nilai Durbin-Watson sebesar 1.714 nilai tersebut berada diantara interval $1.550-2.460$. Dengan demikian model regresi dinyatakan tidak ada gangguan autokorelasi.

\section{d. Uji Heteroskesdastisitas}

Pengujian

heteroskedastisitas

dimaksudkan untuk menguji apakah dalam sebuah model regresi terjadi ketidaksamaan varians residual. Hasil pengujiannya sebagai berikut:

Tabel 5. Hasil Uji Heteroskesdastisitas dengan Glejser Test Model

\begin{tabular}{|c|c|c|c|c|c|}
\hline \multirow[b]{3}{*}{ Model } & \multicolumn{2}{|c|}{ Coefficients $^{\mathrm{a}}$} & \multirow{3}{*}{$\begin{array}{c}\text { StSayardized } \\
\text { Coefficients } \\
\text { Beta }\end{array}$} & \multirow[b]{3}{*}{$\mathrm{t}$} & \multirow[b]{3}{*}{ Sig. } \\
\hline & \multicolumn{2}{|c|}{$\begin{array}{l}\text { UnstSayardized } \\
\text { Coefficients }\end{array}$} & & & \\
\hline & $\mathrm{B}$ & Std. Error & & & \\
\hline $\begin{array}{ll} & \text { (Constant) }\end{array}$ & 4.283 & 1.928 & & 2.222 & .029 \\
\hline Pelatihan (X1) & -.050 & .053 & -.121 & -.930 & .355 \\
\hline Motivasi (X2) & -.019 & .056 & -.047 & -.346 & .730 \\
\hline Budaya organisasi (X3) & .003 & .053 & .007 & .056 & .955 \\
\hline
\end{tabular}

a. Dependent Variable: RES2

Hasil pengujian dengan menggunakan uji glejser diperoleh nilai Sig. > 0,05. Dengan demikian regression model tidak ada gangguan heteroskesdastisitas.

\section{Analisis Deskriptif}

Pada pengujian ini digunakan untuk mengetahui skor minimum dan maksimum, mean score dan standar deviasi dari masing-masing variabel. Adapun hasilnya sebagai berikut:

Tabel 6. Hasil Analisis Descriptive Statistics

\begin{tabular}{|l|r|r|r|r|r} 
& \multicolumn{7}{c}{} & \\
& N & Minimum & Maximum & Mean & Std. Deviation \\
\hline Pelatihan (X1) & 100 & 27 & 46 & 38.02 & 3.851 \\
\hline Motivasi (X2) & 100 & 31 & 46 & 37.80 & 3.824 \\
\hline Budaya organisasi (X3) & 100 & 31 & 48 & 38.18 & 3.729 \\
\hline Kinerja Karyawan (Y) & 100 & 28 & 47 & 38.61 & 3.573 \\
\hline Valid N (listwise) & 100 & & & & \\
\hline
\end{tabular}

Pelatihan diperoleh varians minimum sebesar 27 dan varians maximum 46 dengan mean score sebesar 38,02 dengan standar deviasi 3,851.

Motivasi diperoleh varians minimum sebesar 31 dan varians maximum 46 dengan mean score sebesar 37,80 dengan standar deviasi 3,824.

Budaya organisasi diperoleh varians minimum sebesar 31 dan varians maximum 48 dengan mean score sebesar 38,18 dengan standar deviasi 3,729.

Kinerja karyawan diperoleh varians minimum sebesar 28 dan varians maximum 47 dengan mean score sebesar 38,61 dengan standar deviasi 3,573.

\section{Analisis Verifikatif}

Pada analisis ini dimaksudkan untuk mengetahui pengaruh variabel independen terhadap variabel dependen. Adapun hasil pengujian sebagai berikut: 


$\begin{array}{ccrlrl}\text { a. Analisis } & \text { Regresi } & \text { Linier } & & \text { jika variabel independen } \\ \text { Berganda } & & & \text { mengalami perubahan. Adapun } \\ \text { Uji } & \text { regresi } & \text { ini } & & \text { hasil pengujiannya sebagai } \\ \text { dimaksudkan untuk mengetahui } & & \text { berikut: }\end{array}$
perubahan variabel dependen

Tabel 7. Hasil Pengujian Regresi Linier Berganda

\section{Coefficients $^{\text {a }}$}

Unstandardized

Coefficients

\begin{tabular}{l|r|r|r|r|r} 
Model & \multicolumn{1}{c|}{ B } & Std. Error & Beta & t & \multicolumn{1}{c}{ Sig. } \\
\hline 1 (Constant) & 6.746 & 2.934 & & 2.299 & .024 \\
\hline Pelatihan (X1) & .243 & .081 & .262 & 2.983 & .004 \\
\hline Motivasi (X2) & .304 & .085 & .326 & 3.559 & .001 \\
\hline Budaya organisasi (X3) & .292 & .080 & .304 & 3.644 & .000 \\
\hline
\end{tabular}

a. Dependent Variable: Kinerja Karyawan (Y)

Berdasarkan hasil pengujian pada tabel di atas, diperoleh persamaan regresi $\mathrm{Y}$ $=6,746+0,243 \mathrm{X} 1+0,304 \mathrm{X} 2+$ $0,370 \times 3$

Dari persamaan tersebut dijelaskan sebagai berikut:

1) Konstanta sebesar 6,746 diartikan jika pelatihan dan motivasi tidak ada, maka telah terdapat nilai kinerja karyawan sebesar 6,746 point.

2) Koefisien regresi pelatihan sebesar 0,243, angka ini positif artinya setiap ada peningkatan pelatihan sebesar 0,243 maka kinerja karyawan juga akan mengalami peningkatan sebesar 0,243 point.

3) Koefisien regresi motivasi sebesar 0,304, angka ini positif artinya setiap ada Tabel 8. Hasil Pengujian Koefisien Korelasi Pelatihan Terhadap Kinerja Karyawan

\begin{tabular}{|c|c|c|c|}
\hline & \multicolumn{3}{|c|}{ Correlations $^{\mathrm{b}}$} \\
\hline & & $\begin{array}{l}\text { Pelatihan } \\
\text { (X1) }\end{array}$ & Kinerja Karyawan $(\mathrm{Y})$ \\
\hline \multirow[t]{2}{*}{ Pelatihan (X1) } & Pearson Correlation & 1 & $.606^{* *}$ \\
\hline & Sig. (2-tailed) & & .000 \\
\hline \multirow[t]{2}{*}{ Kinerja Karyawan (Y) } & Pearson Correlation & $.606^{* *}$ & 1 \\
\hline & Sig. (2-tailed) & .000 & \\
\hline
\end{tabular}

peningkatan motivasi sebesar 0,304 maka kinerja karyawan juga akan mengalami peningkatan sebesar 0,304 point.

4) Koefisien regresi budaya organisasi sebesar 0,370, angka ini positif artinya setiap ada peningkatan motivasi sebesar 0,370 maka kinerja karyawan juga akan mengalami peningkatan sebesar 0,370 point.

\section{b. Analisis Koefisien Korelasi}

$$
\text { Analisis koefisien }
$$
korelasi dimaksudkan untuk mengetahui tingkt kekuatan hubungan dari variabel independen terhadap variabel dependen baik secara parsial maupun simultan. Adapun hasil pengujian sebagai berikut: 
Berdasarkan hasil pengujian diperoleh nilai korelasi sebesar 0,609 artinya

Tabel 9. Hasil Pengujian Koefisien Korelasi Motivasi Terhadap Kinerja Karyawan Correlations $^{\text {b }}$

\begin{tabular}{llr|r} 
& & \multicolumn{2}{c}{$\begin{array}{c}\text { Kinerja Karyawan } \\
\text { (Y) }\end{array}$} \\
\hline Motivasi (X2) & Pearson Correlation & 1 & $.649^{* *}$ \\
\cline { 2 - 4 } & Sig. (2-tailed) & & .000 \\
\hline Kinerja Karyawan (Y) & Pearson Correlation & $.649^{* *}$ & 1 \\
\cline { 2 - 4 } & Sig. (2-tailed) & .000 & \\
\hline
\end{tabular}

Berdasarkan hasil pengujian diperoleh nilai korelasi sebesar 0,649 artinya

Tabel 10. Hasil Pengujian Koefisien Korelasi Budaya organisasi Terhadap Kinerja

Karyawan

Correlations $^{\text {b }}$

\begin{tabular}{llr|r} 
& & Motivasi (X2) & $\begin{array}{r}\text { Kinerja Karyawan } \\
\text { (Y) }\end{array}$ \\
\hline Budaya organisasi (X3) & Pearson Correlation & 1 & $.609^{* *}$ \\
\cline { 2 - 4 } & Sig. (2-tailed) & & .000 \\
\hline Kinerja Karyawan (Y) & Pearson Correlation & $.609^{* *}$ & 1 \\
\cline { 2 - 4 } & Sig. (2-tailed) & .000 & \\
\hline
\end{tabular}

Berdasarkan hasil pengujian diperoleh nilai korelasi sebesar 0,609 artinya motivasi memiliki hubungan yang kuat terhadap kinerja karyawan.

Tabel 11. Hasil Pengujian Koefisien Korelasi Pelatihan dan Motivasi secara simultan Terhadap Kinerja Karyawan Model Summary

\begin{tabular}{lr|r|r|rr} 
& & \multicolumn{2}{c}{$\begin{array}{c}\text { Adjusted R } \\
\text { Model }\end{array}$} & \multicolumn{2}{c}{$\begin{array}{c}\text { Std. Error of the } \\
\text { Estimate }\end{array}$} \\
\hline 1 & $.736^{\mathrm{a}}$ & \multicolumn{1}{c|}{ R Square } & \multicolumn{1}{c}{ Square } & \multicolumn{2}{c}{2.368} \\
\hline
\end{tabular}

a. Predictors: (Constant), Budaya organisasi (X3), Motivasi (X2), Pelatihan (X1)

Berdasarkan hasil pengujian diperoleh nilai korelasi sebesar 0,736 artinya pelatihan dan motivasi secara simultan memiliki hubungan yang kuat terhadap kinerja karyawan. c. Analisis Determinasi

Analisis koefisien determinasi dimaksudkan untuk mengetahui besarnya persentase pengaruh dari variabel independen terhadap variabel dependen baik secara parsial maupun simultan. Adapun hasil pengujian sebagai berikut: 
Tabel 12. Hasil Pengujian Koefisien Determinasi Pelatihan Terhadap Kinerja Karyawan Model Summary

\begin{tabular}{lr|r|r|rr} 
Model & & \multicolumn{2}{c}{$\begin{array}{c}\text { Adjusted R } \\
\text { Square }\end{array}$} & \multicolumn{2}{c}{$\begin{array}{c}\text { Std. Error of the } \\
\text { Estimate }\end{array}$} \\
\hline 1 & R & R Square & \multicolumn{1}{c}{ Squar } \\
\hline
\end{tabular}

a. Predictors: (Constant), Pelatihan (X1)

\begin{tabular}{lcclcr}
\multicolumn{2}{c}{ Berdasarkan } & hasil & kontribusi & pengaruh & sebesar \\
pengujian & diperoleh & nilai & $37,0 \%$ terhadap & kinerja \\
determinasi & sebesar & 0,370 & karyawan. & &
\end{tabular}
artinya pelatihan memiliki

Tabel 13. Hasil Pengujian Koefisien Determinasi Motivasi Terhadap Kinerja Karyawan Model Summary

\begin{tabular}{|c|c|c|c|c|}
\hline Model & $\mathrm{R}$ & R Square & $\begin{array}{l}\text { Adjusted R } \\
\text { Square }\end{array}$ & $\begin{array}{l}\text { Std. Error of the } \\
\text { Estimate }\end{array}$ \\
\hline 1 & $.649^{a}$ & .421 & .416 & 2.731 \\
\hline
\end{tabular}

Berdasarkan hasil kontribusi pengaruh sebesar pengujian diperoleh nilai $42,1 \%$ terhadap kinerja determinasi sebesar 0,421 artinya motivasi memiliki karyawan.

Tabel 14. Hasil Pengujian Koefisien Determinasi Budaya organisasi Terhadap Kinerja

Karyawan

\section{Model Summary}

\begin{tabular}{|c|c|c|c|c|}
\hline Model & $\mathrm{R}$ & R Square & $\begin{array}{l}\text { Adjusted R } \\
\text { Square }\end{array}$ & $\begin{array}{l}\text { Std. Error of the } \\
\text { Estimate }\end{array}$ \\
\hline 1 & $.609^{a}$ & .371 & .364 & 2.849 \\
\hline
\end{tabular}

Berdasarkan hasil pengujian diperoleh nilai determinasi sebesar 0,371 artinya budaya organisasi

Tabel 15. Hasil Pengujian Koefisien Determinasi Pelatihan, Motivasi dan Budaya organisasi Terhadap Kinerja Karyawan

Model Summary

\begin{tabular}{|c|c|c|c|c|}
\hline Model & $\mathrm{R}$ & R Square & $\begin{array}{l}\text { Adjusted R } \\
\text { Square }\end{array}$ & $\begin{array}{l}\text { Std. Error of the } \\
\text { Estimate }\end{array}$ \\
\hline 1 & $.745^{\mathrm{a}}$ & .555 & .541 & 2.420 \\
\hline
\end{tabular}

Berdasarkan hasil pengujian diperoleh nilai determinasi sebesar 0,555 artinya pelatihan, motivasi dan budaya organisasi secara simultan memiliki kontribusi pengaruh sebesar 55,5\% terhadap kinerja karyawan, memiliki kontribusi pengaruh sebesar 37,1\% terhadap kinerja karyawan. 
Hipotesis pertama:

Terdapat pengaruh yang signifikan pelatihan terhadap kinerja karyawan.

Hipotesis kedua:

Terdapat pengaruh yang signifikan motivasi terhadap kinerja karyawan.

Hipotesis ketiga:

Terdapat pengaruh yang signifikan budaya organisasi terhadap kinerja karyawan.

Tabel 16. Hasil Uji Hipotesis Pelatihan Terhadap Kinerja Karyawan

Coefficients $^{\mathrm{a}}$

Unstandardized

Coefficients

\begin{tabular}{|c|c|c|c|c|c|}
\hline Model & B & Std. Error & Beta & $\mathrm{t}$ & Sig. \\
\hline $\begin{array}{ll}1 & \text { (Constant) }\end{array}$ & 17.248 & 2.850 & & 6.051 & .000 \\
\hline Pelatihan (X1) & .562 & .075 & .606 & 7.533 & .000 \\
\hline
\end{tabular}

a. Dependent Variable: Kinerja Karyawan $(\mathrm{Y})$

Berdasarkan hasil pengujian pada tabel di atas, diperoleh nilai $t$ hitung $>\mathrm{t}$ tabel atau $(7,533>1,984)$, dengan demikian hipotesis pertama

Tabel 17. Hasil Uji Hipotesis Motivasi Terhadap Kinerja Karyawan

\section{Coefficients}

Unstandardized

Coefficients

Model

B $\quad$ Std. Error yang diajukan bahwa terdapat pengaruh yang signifikan pelatihan terhadap kinerja karyawan diterima.

\begin{tabular}{llr|rrrrr} 
& \multicolumn{1}{c}{ B } & Std. Error & Beta & \multicolumn{1}{c}{ t } & \multicolumn{1}{c}{ Sig. } \\
\hline 1 & 15.685 & 2.727 & & 5.751 & .000 \\
\cline { 2 - 7 } & Motivasi (X2) & .606 & .072 & .649 & 8.449 & .000 \\
\hline
\end{tabular}

a. Dependent Variable: Kinerja Karyawan (Y)

Berdasarkan hasil pengujian pada tabel di atas, diperoleh nilai $\mathrm{t}$ hitung $>\mathrm{t}$ tabel atau $(8,499>1,984)$, dengan demikian hipotesis kedua yang

Tabel 18. Hasil Uji Hipotesis Budaya organisasi Terhadap Kinerja Karyawan

\begin{tabular}{|c|c|c|c|c|c|}
\hline \multirow[b]{2}{*}{ Model } & $\begin{array}{r}\text { C } \\
\text { Unst } \\
\text { Co }\end{array}$ & $\begin{array}{l}\text { efficients }{ }^{\mathbf{a}} \\
\text { hdardized } \\
\text { ficients }\end{array}$ & \multirow{2}{*}{$\begin{array}{c}\text { Standardized } \\
\text { Coefficients } \\
\text { Beta } \\
\end{array}$} & \multirow[b]{2}{*}{$\mathrm{t}$} & \multirow[b]{2}{*}{ Sig. } \\
\hline & $\mathrm{B}$ & Std. Error & & & \\
\hline 1 (Constant) & 16.341 & 2.945 & & 5.548 & .000 \\
\hline Budaya organisasi (X3) & .583 & .077 & .609 & 7.597 & .000 \\
\hline
\end{tabular}

a. Dependent Variable: Kinerja Karyawan (Y)

Berdasarkan hasil pengujian pada tabel di atas, diperoleh nilai t hitung $>\mathrm{t}$ tabel atau $(7,597>1,984)$, dengan demikian hipotesis ketiga yang diajukan bahwa terdapat diajukan bahwa terdapat pengaruh yang signifikan motivasi terhadap kinerja karyawan diterima. 
mengetahui hipotesis simultan yang mana yang diterima.

Hipotesis keempat

Terdapat pengaruh yang

Tabel 19. Hasil Uji Hipotesis Pelatihan, Motivasi dan budaya organisasi Terhadap Kinerja

\section{Karyawan.}

ANOVA $^{\mathrm{a}}$

\begin{tabular}{|c|c|c|c|c|c|}
\hline$\frac{\text { Model }}{1 \quad \text { Regression }}$ & Sum of Squares & df & Mean Square & $\mathrm{F}$ & Sig. \\
\hline $1 \quad$ Regression & 701.586 & 3 & 233.862 & 39.934 & $.000^{\mathrm{b}}$ \\
\hline Residual & 562.204 & 96 & 5.856 & & \\
\hline Total & 1263.790 & 99 & & & \\
\hline
\end{tabular}

a. Dependent Variable: Kinerja Karyawan (Y)

b. Predictors: (Constant), Budaya Organisasi (X3), Pelatihan (X1), Motivasi (X2)

Berdasarkan hasil pengujian pada tabel di atas, diperoleh nilai $\mathrm{F}$ hitung $>\mathrm{F}$ tabel atau $(39,934>2,470)$, dengan demikian hipotesis ketiga yang diajukan bahwa terdapat pengaruh yang signifikan pelatihan, motivasi dan budaya organisasi terhadap kinerja karyawan diterima.

PEMBAHASAN

HASIL

\section{PENELITIAN}

\section{Pengaruh Pelatihan Terhadap} Kinerja Karyawan

Dari hasil analisis diperoleh variabel pelatihan berpengaruh signifikan terhadap kinerja karyawan dengan nilai korelasi sebesar 0,609 artinya kedua variabel memiliki hubungan yang kuat dengan kontribusi pengaruh sebesar 37,0\%. Pengujian hipotesis diperoleh nilai t hitung > $t$ tabel atau $(7,533>1,984)$. Dengan demikian hipotesis pertama yang diajukan bahwa terdapat berpengaruh signifikan antara pelatihan terhadap kinerja karyawan diterima.

2. Pengaruh Motivasi Terhadap Kinerja Karyawan

Dari hasil analisis diperoleh signifikan pelatihan, motivasi dan budaya organisasi terhadap kinerja karyawan. 
4. Pengaruh Pelatihan, Motivasi dan Budaya organisasi Terhadap Kinerja Karyawan

Dari hasil analisis diperoleh variabel pelatihan, motivasi dan budaya organisasi berpengaruh signifikan terhadap kinerja karyawan dengan diperoleh persamaan regresi $\mathrm{Y}=6,746+$ $0,243 \mathrm{X} 1+0,304 \mathrm{X} 2+0,370 \mathrm{X} 3$, nilai korelasi sebesar 0,736 artinya kedua variabel memiliki hubungan yang kuat dengan kontribusi pengaruh sebesar $55,5 \%$ sedangkan sisanya sebesar $44,5 \%$ dipengaruhi faktor lain. Pengujian hipotesis diperoleh nilai $\mathrm{F}$ hitung > F tabel atau $(39,934>2,470)$. Dengan demikian hipotesis keempat yang diajukan bahwa terdapat berpengaruh signifikan pelatihan, motivasi dan budaya organisasi terhadap kinerja karyawan diterima.

\section{KESIMPULAN DAN SARAN Kesimpulan}

1. Pelatihan berpengaruh signifikan terhadap kinerja karyawan nilai korelasi sebesar 0,609 atau sedang dengan kontribusi pengaruh sebesar 37,0\%. Uji hipotesis diperoleh nilai $\mathrm{t}$ hitung $>\mathrm{t}$ tabel atau $(7,533>1,984)$. Dengan demikian terdapat pengaruh yang signifikan antara pelatihan terhadap kinerja karyawan pada PT. Bank Mandiri, Tbk di Jakarta.

2. Motivasi berpengaruh signifikan terhadap kinerja karyawan dengan nilai korelasi sebesar 0,649 atau kuat dengan kontribusi pengaruh sebesar 42,1\%. Uji hipotesis diperoleh nilai $\mathrm{t}$ hitung $>\mathrm{t}$ tabel atau $(8,499>1,984)$. Dengan demikian terdapat pengaruh yang signifikan antara motivasi terhadap kinerja karyawan pada PT. Bank Mandiri, Tbk di Jakarta.

3. Budaya organisasi berpengaruh signifikan terhadap kinerja karyawan dengan nilai korelasi sebesar 0,554 atau sedang dengan kontribusi pengaruh sebesar $37,1 \%$. Uji hipotesis diperoleh nilai $\mathrm{t}$ hitung $>\mathrm{t}$ tabel atau $(7,597$ $>$ 1,984). Dengan demikian terdapat pengaruh yang signifikan antara budaya organisasi terhadap kinerja karyawan pada PT. Bank Mandiri, Tbk di Jakarta.

4. Pelatihan, motivasi dan budaya organisasi berpengaruh signifikan terhadap kinerja karyawan dengan nilai korelasi sebesar 0,736 atau kuat dengan kontribusi pengaruh sebesar $55,5 \%$ sedangkan sisanya sebesar 44,5\% dipengaruhi faktor lain. Uji hipotesis diperoleh nilai $\mathrm{F}$ hitung > F tabel atau $(39,934>$ $2,470)$. Dengan demikian terdapat pengaruh yang signifikan antara pelatihan, motivasi dan budaya organisasi secara simultan terhadap kinerja karyawan pada PT. Bank Mandiri, Tbk di Jakarta.

\section{Saran}

1. Perusahaan harus memberikan kesempatan yang sama pada setiap karyawan untuk memacu semangat kerja dalam rangka memajukan lembaga sehingga mendapatkan kesempatan untuk meraih kedudukan yang diinginkan.

2. Perusahaan harus mengakomodir karyawan yang dengan programprogram yang lebih inovatif agar sesuai dengan dengan tujuan yang dikehendaki karyawannya.

3. Perusahaan perlu mengadakan 
budaya organisasi-budaya organisasi maupun program lainnya untuk lebih mendorong karyawan memiliki cukup kemampuan yang diperlukan guna menunjang tercapainya tujuan organisasi dengan baik.

4. Pengaruh secara simultan dari pelatihan, motivasi dan budaya organisasi terhadap kinerja karyawan sebesar 55,5\% hal ini menunjukkan bahwa kondisi masing-masing variabel bebas harus ditingkatkan secara signifikan. oleh karenanya disarankan kepada penelitian berikutnya agar melakukan penelitian yang relevan dengan cara memperbaiki indikator yang masih tidak baik atau dengan menambah indikator pertanyaan dan jumlah responden penelitian sehingga akan dapat lebih diketahui variabel yang paling memberikan kontribusi positif bagi perusahaan

\section{DAFTAR PUSTAKA}

Affandi, A., et al. (2020). Optimization of MSMEs Empowerment in Facing Competition in the Global Market during the COVID-19 Pandemic Time. Systematic Reviews in Pharmacy, 11(11), 1506-1515.

Agung Nugroho (2014). Strategi Jitu Dalam Memilih Metode Statistik Peneltian, Andi, Yogyakarta.

Algifari (2015). Analisis Regresi untuk Bisnis dan Ekonomi. Yogyakarta: BPFE.

Anwar Prabu Mangkunegara, "Manajemen Sumber Daya Manusia Perusahaan”. Remaja
Rosdakarya. Bandung, 2015.

Carrel, Michael R., Elbert, Norbert F., Hatfield, Robert D., "Human

Resource. Management: Global Strategies for Managing a

Diverse Workplace", 2015

Danang Mulyana (2016), Jurnal Manajemen, Vol.2 No.3, ISSN: 2252-6554. Pengaruh Pelatihan, Motivasi Dan Budaya organisasi Terhadap Kinerja Karyawan Pada PT. Semarang Makmur

Danang Sunyoto, "Metodologi Penelitian Akuntansi". PT Refika Aditama, Bandung, 2016

Edwin B Flippo, "Prinsip-Prinsip Sumber Daya Manusia”, Edisi ke Duabelas, Erlangga, Jakarta, 2014.

Edy Sutrisno "Sumber Daya Manusia", PT. Gramedia, Surabaya, 2016.

Garry Dessler, "Human Resources Management", Prenticehall, International Inc, London, 2013.

Ghozali "Aplikasi Analisis Multivariate dengan Program SPSS”, Edisi Kelima, Badan Penerbit Undip, Semarang, 2016

Handoko, "Manajemen Personalia dan Sumberdaya Manusia", Edisi Kelima, BPFE UGM, Yogyakarta, 2012.

Hasibuan, SP, "Dasar-dasar Perbankan", Haji Masagung, Jakarta, 2016.

Inpres No.6/2014, tentang peningkatan daya saing menghadapi Masyarakat Ekonomi ASEAN

Kharis Ismu Fadli (2011). Studi Mengenai Impulse Buying 
dalam Penjualan Online.

Semarang : Skripsi Universitas Diponegoro

Kusriyanto,

Bambang.

"Meningkatkan Efektifitas

Karyawan”, JPT. Pustaka

Binaman Pressind, Jakarta,

2014

Miftah Thoha "Kepemimpinan

Dalam Manajemen”, Edisi

Pertama, PT. Raja Grafindo,

Jakarta, 2016.

Nurhayati, et al. (2018). Pelatihan

Pembukuan Di UKM Sumpia

Chantika Dewi Cimindi

Cimahi. Laporan Program

Kepakaran Fisip Unpas

Pengabdian Kepada

Masyarakat Tahun Akademik 2016/2017, 1-22.

Nurjaya, N., et al. (2021). Pengaruh

Kompetensi Sumber Daya

Manusia Dan Kemampuan

Pemanfaatan Teknologi

Terhadap Kinerja Aparatur

Desa Pada Kantor Kepala Desa

Di Kabupaten Gunungkidul,

Yogyakarta. JENIUS (Jurnal

Ilmiah Manajemen Sumber

Daya Manusia), 4(3), 332-346.

Oemar Hamalik, Oemar,

"Manajemen Pengembangan

Manajemen", PT. Remaja

Rosda Karya, Bandung, 2014.

Robbins, S. \& Judge, T, "Organizational Behavior",

Edisi keduabelas, Prentice Hall, 2014.

Sagala, Syaiful. "Supervisi

Pembelajaran dalam Profesi

Pendidikan". Alfabeta,

Bandung, 2013.

Salam, Darma Setyawan,

"Manajemen Pemerintahan

Indonesia”, Djambatan,

Jakarta, 2014.
Sedarmayanti. "Manajemen Sumber Daya Manusia, Reformasi Birokrasi dan Manajemen Pegawai Negeri Sipil”, Cetakan Kelima, PT Refika Aditama, Bandung, 2016.

Singgih Santoso (2015). Menguasai Statistik Multivariat. Jakarta: PT Elex Media Komputindo.

Siregar, Syofian, "Metode Penelitian Kuantitatif”. PT Fajar Interpratama Mandiri, Jakarta, 2015

Sudjana (2014) Metode Statistika, Bandung: Tarsido.

Sugiyono (2017), Metode Penelitian Administrasi : dilengkapi dengan Metode $R \& D$, Bandung: Alfabeta.

Suharsimi Arikunto "Prosedur Penelitian Suatu Pendekatan Praktek", PT. Rineka Cipta, Jakarta, 2015.

Sunarsi, D. (2017). Pengaruh Kepemimpinan Dan Budaya Organisasi terhadap Kinerja Karyawan Pada Cabang Pembantu Bank DKI Pondok Labu-Jakarta Selatan. JENIUS, 1(2), 21.

Sutrisno, Edy, "Sumber Daya Manusia”, PT. Gramedia, Surabaya, 2016.

Syofian Siregar, "Statistika Deskriptif Untuk Penelitian", PT Raja Grafindo Persada, Jakarta, 2015.

Thoha, Miftah, "Perilaku Organisasi, Konsep Dasar dan Aplikasinya”, Raja Grafindo Persada, Jakarta. 2015

Tulus, Tu'u, "Peran Disiplin pada Perilaku dan Prestasi Belajar. PT. Grasindo, Jakarta, 2004.

Udang-Undang Nomor 5 Tahun 1984 yang mengatur tentang industri 
manufacturer menyeburkan bahwa industri merupakan kegiatan ekonomi yang mengolah bahan mentah, bahan baku, setengah jadi menjadi barang jadi dengan nilai yang lebih tinggi.

Veithzal Rivai, , "Manajemen Sumber Daya Manusia Untuk Perusahaan", Raja Grafindo Persada, Jakarta, 2015.
Wawan S. Suherman, "Kurikulum Berbasis

Kompetensi

Pendidikan Jasmani Teori dan Praktik Pengembangan", FIK UNY, Yogyakarta, 2014.

Yannik Ariyati (2018), Jurnal Equilibria, Vol.5 No.2, P-ISSN: 2503-1546.

Pengaruh

Pelatihan, Motivasi dan Keterlibatan Karyawan terhadap Kinerja. 